\title{
Engin fræðastörf á vinnutíma
}

Á sokkabandsárum mínum á Landspítala á sjöunda áratug síðustu aldar var pað mjög til umræðu meðal yngri manna að spítalinn pyrfti að gerast raunverulegur háskólaspítali sem sinnti af alvöru öllum höfuðskyldum slíkrar stofnunar, pjónustu, kennslu og fræðum. Par fór fremstur Helgi Valdimarsson. En petta markmið var raunar líka yfirlýst keppikefli margra kennara læknadeildar. Mætti nefna til peirrar sögu Davíð Davíðsson, Theódór Skúlason, Jón Porsteinsson og fleiri. Hvað skorti Landspítalann á pennan sæmdartitil?

Jú, ytri umgjörðin virtist traust með lögbundnu verkstjórahlutverki nokkurra prófessora í helstu greinum læknisfræðinnar, en sú skipan studdist við 38. grein laga um Háskóla Íslands. En pað náði skammt. Háskóli Íslands átti sem slíkur engin formleg ítök eða áhrif á stjórn spítalans og að sjálfsögðu var aldrei til umræðu að háskólinn ætti spítalann eins og sums staðar gefur góða raun. Engin lagaákvæði gerðu ráð fyrir vísindastörfum á spítalanum og pað var varla gert ráð fyrir pví að læknadeild ætti samastað á spítalanum pótt ekki væri beinlínis amast við henni. Örfáar fræðigreinar spítalalækna birtust á stangli í ritrýndum tímaritum. Engar sérstakar fjárveitingar voru ætlaðar til kennslustarfa sérfræðinga eða vísindastarfa yfirleitt. Verkleg kennsla var óskipulögð. Um pjónustu við sjúklinga verður ekki fjallað í pessu viðfangi.

Prátt fyrir pað óx fræða- og kennslustörfum fiskur um hrygg og viðhorfin breyttust. Mannaflinn styrktist og fleiri komu til starfa með rannsóknarpjálfun og metnað fyrir háskólahlutverki spítalans. Skömmu eftir aldamótin 2000 var talið að tilvitnanir í fræðigreinar Landspítalalækna væru hlutfallslega jafnmargar eða fleiri en flestra sambærilegra stofnana á Norðurlöndum. Landspítali átti pá aðild að um 40\% vísindagreina sem íslenskir fræðimenn birtu á alpjóðavettvangi. Auðvitað nutu peir samstarfs við Íslenska erfðagreiningu og fleiri vísindastofnanir. Eldhugar eins og Guðmundur Porgeirsson, Kristján Erlendsson, Sigurður Guðmundsson, Runólfur Pálsson og fleiri umbyltu kennsluháttum læknadeildar. Engu að síður var hinn kerfislægi vandi enn fyrir hendi og beið úrlausnar.

Samkvæmt lögum um heilbrigðispjónustu frá 1990 skyldi framkvæmdastjórn stýra daglegum rekstri sjúkrahúsa og vera forstjóra til ráđuneytis. Í framkvæmdastjórn Landspítala sátu auk forstjóra lækningaforstjóri, hjúkrunarforstjóri og framkvæmdastjóri fjármála og tæknimála. Á fundum framkvæmdastjórnar sátu einnig formaður læknaráðs og fulltrúi læknadeildar Háskóla Íslands.

Eftir sameiningu Sjúkrahúss Reykjavíkur og Landspítala vorið 2000 var hins vegar ekki óskað eftir nærveru hinna tveggja síðarnefndu. Pví miður varð petta ekki til að styrkja stöðu háskólans á hinum nýja spítala. Hins vegar fékk spítalinn nafnið Landspítali-háskólasjúkrahús. Viðbótin - háskólasjúkrahús - hvarf pó hægt og hljóðlega með nýjum lögum um heilbrigðispjónustu árið 2007. Pá var stjórnarnefnd Ríkisspítala lögð niður en hún hafði verið í stjórnskipulagi landssjúkrahússins frá árinu 1935. Lengst af höfðu fulltrúar vísinda og fræða getað komið sjónarmiðum sínum á framfæri með aðild að peim vettvangi. Nýtt sviðakerfi var innleitt, en formleg aðkoma nokkurra prófessora að stjórn spítaladeilda afnumin. Eflaust voru ákveðin rök fyrir peirri ráðstöfun, par sem forgangur í stjórnun sjúkrahúsa var víða að færast í átt til fjármálastýringar, stundum á kostnað faglegra sjónarmiða. Áherslubreytingin var hins vegar ótvíræð og afdrifarík. Samstarfssamningur Háskóla Íslands og Landspítala, sem gerður var árið 2006 eftir langt en málefnalegt andóf læknadeildar, leiddi ekki til neinna merkjanlegra úrbóta.

Án efa hefði hið nýja stjórnskipulag Landspítala pó getað tekist vel ef hugað hefði verið vandlega að akademískum styrkleika stjórnenda, jafnframt öðrum nauðsynlegum verðleikum peirra. Líkur benda til að petta hafi ekki tekist til fullnustu. Tvö nýleg dæmi koma í hug. Ég var staddur á göngudeild Landspítalans og heyrði par á tal ungs sérfræðings við millistjórnanda. Hinn fyrrnefndi ræddi lyfjarannsókn sem hann hugðist taka pátt í með samstarfi við norræna háskólaspítala. Hinn síðarnefndi sagði: „एаð er ekki gert ráð fyrir fræðastörfum á vinnutíma“. Hitt dæmið er klukkutímalöng kynning par sem vaskur klínískur sviðsstjóri kynnti framtíðarsýn sína. Par var ekki orði yrt að kennslu eða fræðastörfum. Pessi dæmi auk ýmissa annarra sem hafa borið fyrir eyru benda til pess að ýmsir millistjórnendur hafi misst sjónar á hinu príeina hlutverki háskólaspítala, pjónustu, kennslu og vísindum. Petta hlutverk verður ekki sundurgreint pví að alpjóðleg reynsla sýnir að akademísk kennsla og fræði styrkja pjónustu við sjúklinga og öfugt. Fræðin geta raunar líka leitt til arðvænlegrar nýsköpunar eins og dæmi sanna. Enginn efast um góðan vilja og stefnufestu forstjóra Landspítala og nánustu samstarfsmanna hans, en líklega er við ramman reip að draga. Birtum vísindagreinum Landspítalalækna og tilvitnunum fer pví miður fækkandi og spítalinn er ekki lengur í norrænum fararbroddi á pessu sviði, heldur nálægt botnsætinu.

Í Bandaríkjunum er talið að rekstur háskólasjúkrahúsa sé 30\% dýrari en annarra spítala, en háskólastarfið bjargi mannslífum. ${ }^{1}$ Nýleg rannsókn² á kostnaði norrænna háskólasjúkrahúsa (Ísland var ekki með) bendir til að umframkostnaður peirra vegna kennslu og fræðahlutverksins sé $20-30 \%$. Pessu kostnaðarsama hlutverki Landspítala parf að halda á lofti í viðræðum við stjórnvöld og Alpingi, en jafnframt hafa í huga að hið príeina hlutverk verður aldrei leyst upp í aðgreinda pætti. Á vinnutíma eiga peir samleið og öllum verður að sinna, stundum samtímis.

\section{Heimildir}

1. Austin Frakt. Teaching Hospitals Cost More, but Could Save Your Life. New York Times, 5. júní 2017.

2. Medin E, Anthun KS, Häkkinen U, Kittelsen SA, Linna M, Magnussen J. Cost efficiency of university hospitals in the Nordic countries: a crosscountry analysis. Eur J Health Econ 2011; 12: 509-19.

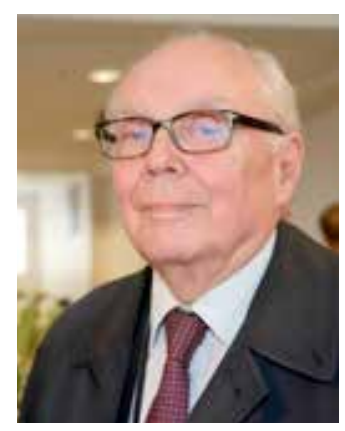

Pórður Harðarson

Prófessor emeritus, sérfræðingur í hjartalækningum

thordhar@landspitali.is

\section{No academic work during hospital hours}

Pórður Harðarson MD PhD, cardiologist.

Former Chief of Medicine, National University Hospital, Iceland. Former Professor of Medicine and Dean of Medical School, University of Iceland.

DOI: 10.17992/lbl.2019.09.243 